\title{
Rock magnetism and microscopy of the Jacupiranga alkaline-carbonatitic complex, southern Brazil
}

\author{
Luis M. Alva-Valdivia ${ }^{1,2}$, M. Perrin² ${ }^{2}$ María L. Rivas-Sánchez ${ }^{1}$, Avto Goguitchaichvili ${ }^{1}$, \\ Héctor López-Loera ${ }^{3}$, Omar Ferreira Lopes ${ }^{4}$, and Thiago Bastos Bonás ${ }^{5}$ \\ ${ }^{1}$ Laboratorio de Paleomagnetismo y Geofisica Nuclear, Instituto de Geofisica, UNAM, Ciudad Universitaria, \\ 04510 México DF, Mexico \\ ${ }^{2}$ Géosciences Montpellier, Université Montpellier II, 34095 Montpellier Cedex 05, France \\ ${ }^{3}$ Instituto Potosino de Investigación Científica y Tecnológica A. C., Depto. Geología Económica, \\ San Luis Potosí, S. L. P., Mexico \\ ${ }^{4}$ Universidade Federal do Paraná, Departamento de Geologia, Jardim das Américas, Curitiba, Paraná, Brazil \\ ${ }^{5}$ Planejamento de Lavra/Geologia, BUNGE Fertilizantes S/A Unidade Cajati, Sao Paulo, Brazil
}

(Received November 10, 2007; Revised July 20, 2008; Accepted July 21, 2008; Online published January 23, 2009)

\begin{abstract}
This study of the Cajati deposit provides evidence that the ore was neither purely hydrothermal, nor volcanic in origin, as previous workers have proposed. The ores were formed from magnetite-rich magmas, hydrothermally altered and intruded at an indicated crustal depth in excess of $500 \mathrm{~m}$. The mineralogical and textural association between magnetite and magnesioferrite in the carbonatite, and between the titanomagnetite and magnesioferriteTi mineralization in the pyroxenite of hedenbergite, seems to be analog mineralizations strongly related to the ionic substitution of $\mathrm{Fe}^{2+}$ by $\mathrm{Mg}$. Relatively high $Q$ ratios $(\geq 5)$ for Jacupirangite-pyroxenite may indicate a thermo remanent magnetization (TRM) by the ore during post-metamorphic cooling, however it can also be developed from chemical remanent magnetization (CRM). Vector plots for the pyroxenite samples show reasonably linear and stable magnetic components. The intensity decay curves show that only two components of magnetizations are likely present. Continuous susceptibility measurements with increasing temperature show that the main magnetic phase seems to be magnetite. Maghemite is probably produced during the cooling process. Susceptibility recorded from low temperature (liquid nitrogen $\left(-196^{\circ} \mathrm{C}\right)$ ) to room temperature produces typical curves, indicating Verwey transition of magnetite. Hysteresis parameters point out that nearly all values fall in a novel region of the Day plot, parallel to but below magnetite SD + MD mixing curves.
\end{abstract}

Key words: Rock-magnetism, microscopy, Jacupiranga complex, Brazil.

\section{Introduction}

Some authors have focused on different aspects, such as relationships between petrology, and observed aeromagnetic anomalies and physical properties to define geological and structural units and then mapped these units to establish a correspondence between magnetic petrology and rock-magnetic properties. Microscopy and rock-magnetic properties appear to be appropriate tools for investigating this particular carbonatitic-ore deposit (Alva-Valdivia et al., 1991; Skilbrei et al., 1991; Henkel, 1994; Alva-Valdivia and Urrutia-Fucugauchi, 1995, 1998; Alva-Valdivia et al., 2000, 2001, 2003a, b; Schmidt et al., 2007 and references therein; Vahle et al., 2007; Direen et al., 2008). If the ores were initially magma of magnetite, they would have cooled rapidly and acquired a stable thermoremanent magnetization (TRM). Different forms of thermo-chemical processes, which may occur during and after emplacement of magnetite-ores may result in recrystallization of oxide minerals. Hence, a TRM may be partially or completely replaced by a chemical remanent magnetization (CRM). A

Copyright (c) The Society of Geomagnetism and Earth, Planetary and Space Sciences (SGEPSS); The Seismological Society of Japan; The Volcanological Society of Japan; The Geodetic Society of Japan; The Japanese Society for Planetary Sciences; TERRAPUB. hydrothermal origin of the ores at relatively low temperatures would entail acquisition of CRM rather than TRM.

The aim of this paper is to analyze the results of microscopy and rock-magnetism of the Jacupiranga complex (Cajati deposit).

\section{Geology and Mineralization}

The Jacupiranga alkaline-carbonatitic complex is located in the southeastern region of Brazil $\left(48^{\circ} 09^{\prime} \mathrm{W}, 24^{\circ} 41^{\prime} \mathrm{S}\right)$, Cajati mine, $230 \mathrm{~km}$ from São Paulo. This has been an important phosphatic rock producer that exploits low-grade carbonatitic ore (Brandão and Sant'Agostino, 2004). The carbonatite belongs to the Jacupiranga Ultramafic Alkaline Complex, a classical geological occurrence that was first described by Melcher (1954) as an ellipsoid intrusive body with a NNW-orienting axis $(10.5 \times 6.7 \mathrm{~km})$, covering approximately $65 \mathrm{~km}^{2}$, with Early Cretaceous age (131 My, Ruberti et al., 2000). As a Juquiá's Complex, Jacupiranga is also emplaced into Precambrian basement and consists of silicate and carbonatitic rocks. One of its silicate rocks is widely known as "jacupirangite". Among carbonatitic phases, there are different compositions (calciocarbonatites to magnesiumcarbonatites) forming independent plugs, dykes and dyke swarms (Fig. 1). 


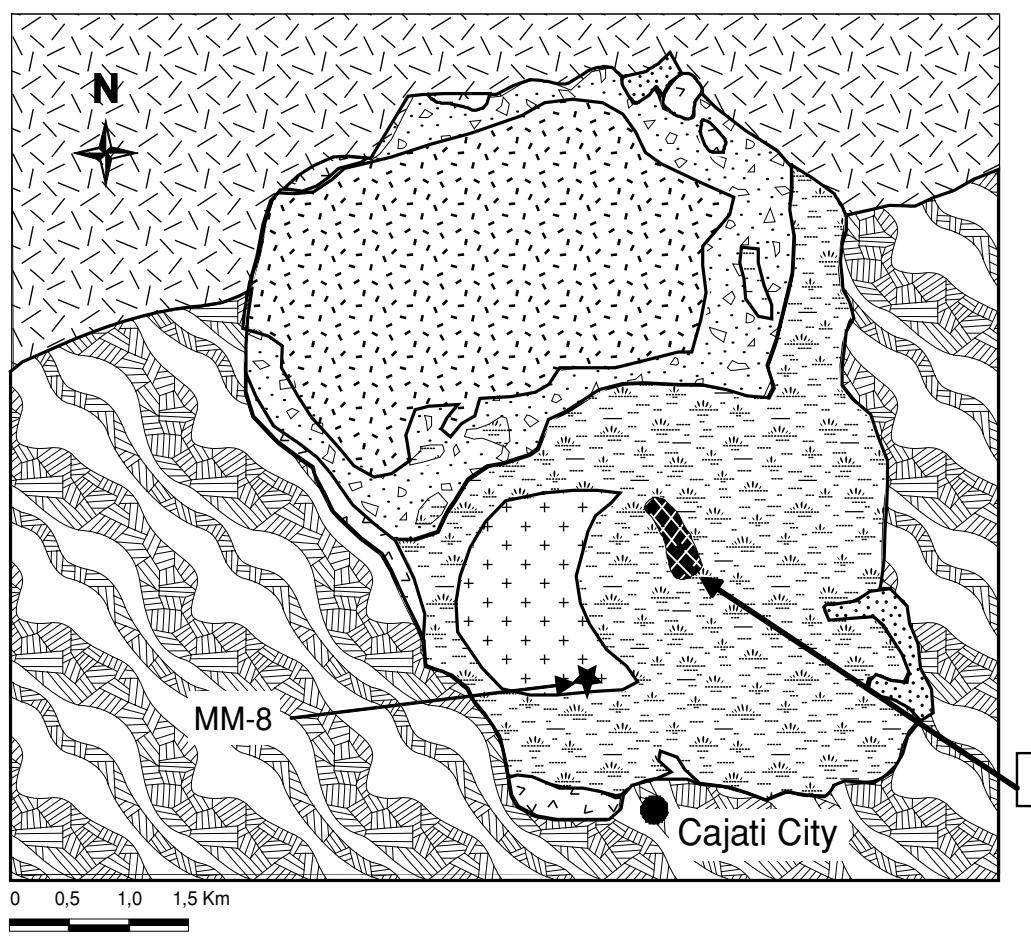

Legend

$\because \because:$ Dunite

NXy Carbonatite

$\pm=$ Jacupiranguite

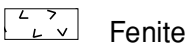

$++\quad$ ljolite

LC Granodiorite

Gneis basement

$\because \because \because$ Swamp

Assimilation zone

* Paleomagnetic site

\section{El Morro Mine}
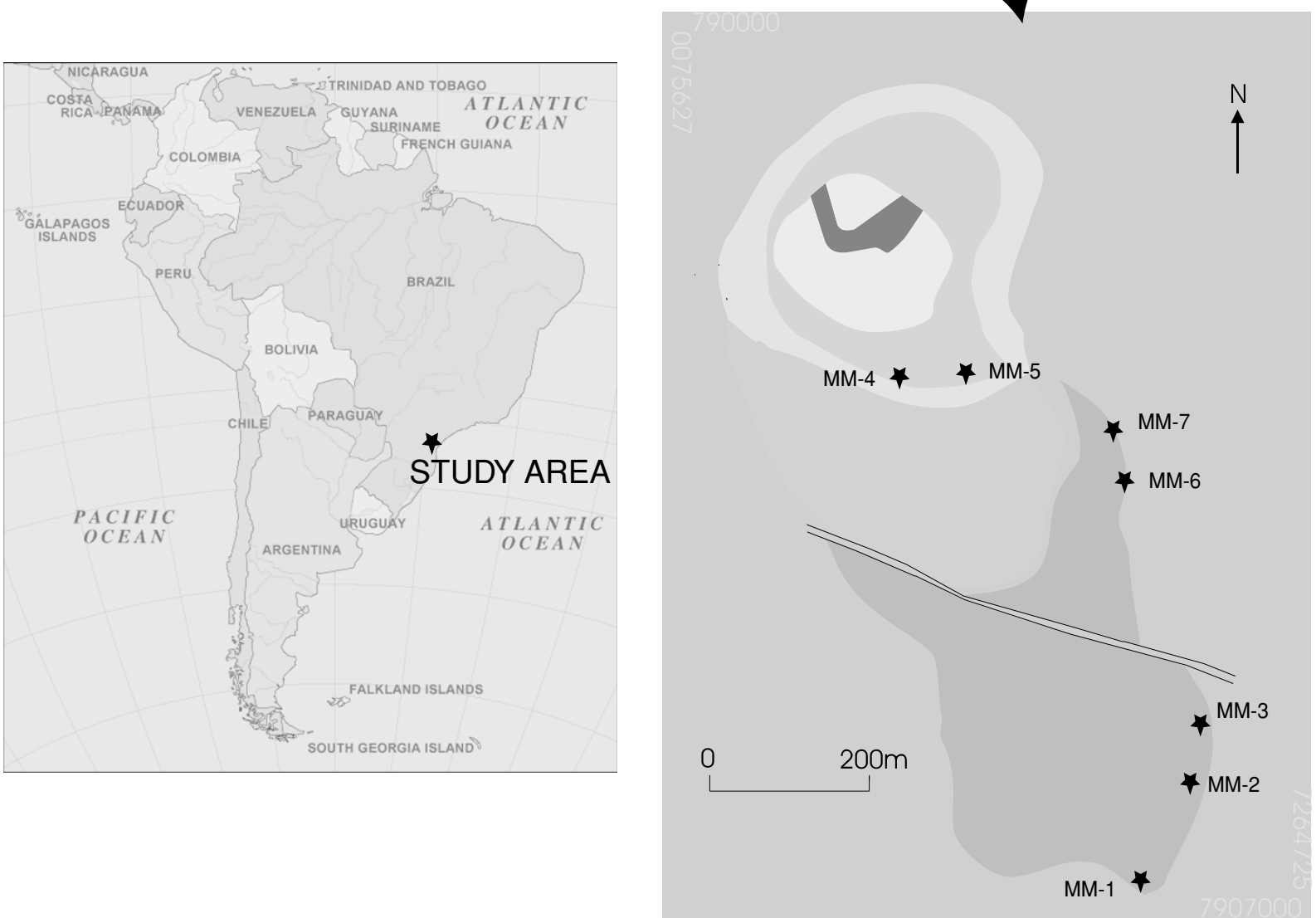

Fig. 1. Simplified regional and local geological map of the Cajati Mine, Brazil. Figure at lower right is all carbonatite (Table 1 includes lithology and text for details).

The orebody is basically composed of carbonatites, and it presents an internal arrangement with specific mineralogical and structural features defining several ore lithologies, as a consequence of at least five recurring magmatic events. The main mineralized geological settings can be recognized as carbonatitic portions (both calcic and dolomitic composition) separated by specific features as well as other lithological ore types, with the most remarkable being minor portions of phoscoritic composition. An important 20- to 30$\mathrm{m}$ wide faulting zone crosses the orebody in the SE-NW 
direction and splits the carbonatite. The contact between carbonatite and jacupirangite shows a remarkable reaction zone between the jacupirangite host rock and intrusive carbonatitic liquid (Bonás, 2001).

The carbonatites are apatite-rich, which formed a pure carbonatitic low-grade ore exploited for almost 30 years (Alves and Hagni, 2004). Some of the geological and mineralogical features influence the industrial processes for this ore. At the Jacupiranga Complex the outcropping carbonatite is continuous over reasonable extensions, which allows a significant separation from silicate rocks, unlike several other apatite-carbonatitic Brazilian ores.

The original lateritic mantle was exhausted, since the in the 1970s. Fresh rock is now mined, although it contains low levels of $\mathrm{P}_{2} \mathrm{O}_{5}$, to produce apatite concentrate, which is used for phosphoric acid manufacture. The low grade of the ore necessitated the development of an industrial-specific processing that allowed making the best use of the whole material, resulting in several by-products (among them carbonatic and iron raw materials for cement manufacturing, dolomite for agricultural lime and phosphogypsum).

\section{Methods of Study}

We collected 56 drill-core samples from eight sites of host-rocks and ore (jacupirangite, phoscorite and ijolite) from the cut exposures in the open-pit and surroundings of the mine (Fig. 1). Six to eight cores were taken at each site with a portable gasoline-powered drill and oriented with an inclinometer, magnetic and sun compass.

Remanent magnetization was measured with a JR-5 spinner magnetometer. The stability and vectorial composition of the natural remanent magnetization (NRM) of each sample was investigated by step-wise alternating field (AF) and thermal demagnetization. AF demagnetization was carried out in 8-12 steps up to $100 \mathrm{mT}$ using a Schonstedt AF demagnetizer in the three-axes stationary mode. Stepwise thermal demagnetization up to $580^{\circ} \mathrm{C}$ using a non-inductive Schonstedt furnace was carried out on one sample per flow. Room-temperature low-field magnetic susceptibility $k$ was measured with a KLY-2 bridge (AGICO, Brno). Continuous susceptibility measurements (i.e., $k-T$ low and hightemperature curves) were obtained using a Highmoor instrument. Magnetic hysteresis loops were measured with a 'MicroMag' alternating gradient force magnetometer. Associated IRM acquisition and DC back-field demagnetization curves were also acquired with this instrument.

\section{Microscopy}

Petrography and oxide mineral observations were carried out with an ore microscope using thin-polished sections and oil immersion, respectively, on a characteristic sample from each site. Direct observation of both transparent and opaque minerals may assist in obtaining an understanding of the nature of their magnetism and in estimating the origin of mineralization.

The microscopic study was performed with transmitted and reflected light in an Olympus BX30. Samples from each site were studied by electron probe X-ray microanalyzer (EPMA), using a JEOL, JXA 8900-R, with $20 \mathrm{Kv}$ of acceleration voltage and $20 \mathrm{~s}$ acquisition time, in order to determine the composition and mineral textural relationships.

\subsection{Carbonatite}

Carbonatite was sampled at sites MM-1, MM-2, and MM-3 (Fig. 2). It shows a white to greyish color and is formed by a coarse grain granular mosaic (500-3000 $\mu \mathrm{m})$ grading to fine grains $(<200 \mu \mathrm{m})$. The main minerals showing a granular alotriomorphic texture are: calcite, dolomite, aragonite, pectolite, apatite, diopside, and complex minerals of titanium, calcium, and/or zirconium. Leafs of phlogopite are present in minor proportion. Metallic minerals, such as magnetite, magnesioferite, pyrite, and marcasite, are filling open spaces between the primary ones. It is classified as intrusive igneous affected by contact metamorphism.

Site MM-1 shows massive magnetite varying from 7 to $500 \mu \mathrm{m}$ size, filling open spaces between the grain minerals of the rock in a proportion ranging from $35 \%$ to $5 \%$. Massive magnetite is formed by the union of various crystals. Magnesioferrite is identified by its mineral chemistry. It is closely associated to magnetite and shows a massive shape, with grains reaching up to $560 \mu \mathrm{m}$. In general, magnetite is not altered, but it also appears to be closed associated with geikielite and apatite or contains geikielite sandwich-type lamellae. Geikielite also replaces magnetite and dolomite along its borders. EPMA analyses detect a significant amount of $\mathrm{MgO}$ (3-10 wt.\%) due to substitution of $\mathrm{Fe}^{2+}$ by $\mathrm{Mg}$.

Apatite euhedral crystals up to $250 \mu \mathrm{m}$, dolomite in minor proportion $(<150 \mu \mathrm{m})$, and pectolite $(<50 \mu \mathrm{m})$ are completely surrounded by magnetite. Also, altered pyrite (marcasite) occupies open spaces in the magnetite. The textural relationship of magnetite, aragonite, and pyrite and its mineralogical association with the primary minerals suggest a deposition soon after carbonatite formation resulting from hydrothermalism.

In sites MM-2 and MM-3, the magnetite proportion is lower that $5 \%$ and decreases gradually in the samples 03M008 to 03M022. In addition to the magnetite reduction, it is remarkable an important decrease in the grain size of the host rock $(<100 \mu \mathrm{m})$.

\subsection{Ultramafic rocks}

The ultramafic rocks (sites MM-3 to MM-6, Fig. 3(a)(d)) are a remarkable olive-green color and have a coarsegranular grain texture $(220-1000 \mu \mathrm{m})$. They are composed of an equigranular mosaic formed mainly by pyroxene $(\sim 65 \%)$ of hedenbergite and diopside varieties. Sodium plagioclase, microcline, orthoclase, calcite, apatite, hornblende, phlogopite, and tremolite are present in minor proportion. Sericite and clay are formed by alteration of orthoclase/microcline, actinolite, tremolite, and chlorite replacing pyroxene. Secondary minerals (quartz and chlorite) are in thin veins.

The metallic minerals (titanomagnetite, ilmenite, pyrite and pyrrhotite) fill open spaces in the host rock forming parts (up to $6 \mathrm{~mm}$ ) connected by thin veins that in general follow the border of the primary grains. Titanomagnetite is present in massive form, with grains varying in size from $380 \mu \mathrm{m}$ to $6 \mathrm{~mm}$. It has approximately $12 \%$ Ti content slightly altered to titanohematite, observed with 

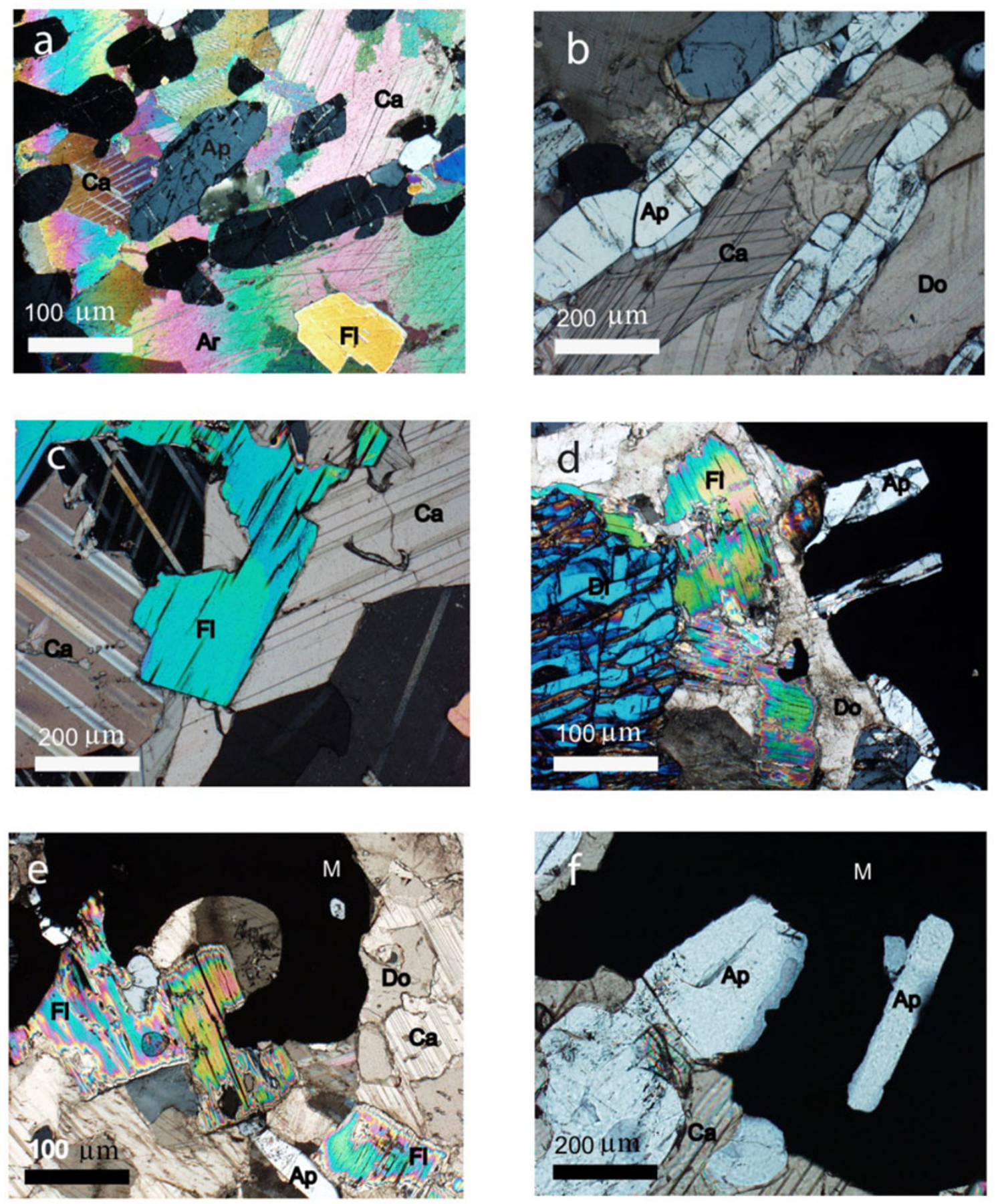

Fig. 2. Representative photomicrographs of carbonatite using crossed nichols and transmitted light. (a) Granular mosaic of Ca, Ap, and Fl. Ca is replaced by Ar along its borders. (b) Ca, Ap, and Do in granular texture. (c) Ca associated to Fl sheets. (d) Granular Di in contact with Do, Ap, and $\mathrm{Fl}$ sheets. $\mathrm{M}$ is intruding into the rock through fractures replacing Do. M-Do association explains the $\mathrm{MgO}$ content in the chemical composition of $\mathrm{M}$. $\mathrm{MgO}$ is between 3-10\%, due to substitution of $\mathrm{Fe}^{2+}$ by $\mathrm{Mg}$. When $\mathrm{M}$ is associated with Ap, it is along the borders of the columnar crystals of Ap. (e) Granular mosaic of $\mathrm{Ca}$, Do, Ap and Fl. Massive M occupies open spaces between the grain borders. (f) Massive M is surrounding Ap columnar crystals, sometimes embedded into the $\mathrm{M} . \mathrm{M}=$ magnetite, $\mathrm{He}=$ hedenbergite, $\mathrm{Ca}=$ calcite, $\mathrm{Ap}=$ apatite, $\mathrm{Fl}=$ phlogopite, $\mathrm{Do}=$ dolomite, $\mathrm{Di}=$ diopside, $\mathrm{Ar}=$ aragonite.

graphic and lamellar intergrowths of ilmenite and ferrian spinel $\mathrm{Mg}(\mathrm{Al}, \mathrm{Fe})_{2} \mathrm{O}_{4}$ in a trellis-type texture. This spinel also forms stars along the crossing lines of the titanomagnetite or as exsolution emulsion type distributed along the microfractures in the titanomagnetite (Fig. 4). Acicular geikielite was observed in fractures and in open spaces replacing to titanomagnetite. Pyrite and pyrrhotite form veins up to $3 \mathrm{~mm}$ thick in the host rock and fill open spaces in the titanomagnetite.

\subsection{Brechoid rocks}

Brechoid rocks were sampled at site MM-7, which is the contact between carbonatite and ultramafic rocks (samples 03M046 and 03M047). For carbonatitic rock, magnetite is the main magnetic mineral forming isles up to $1.5 \mathrm{~mm}$ in the host rock. Magnetite shows a geikielite lamellastrellis type, and it also is replaced along its borders. Mag- 

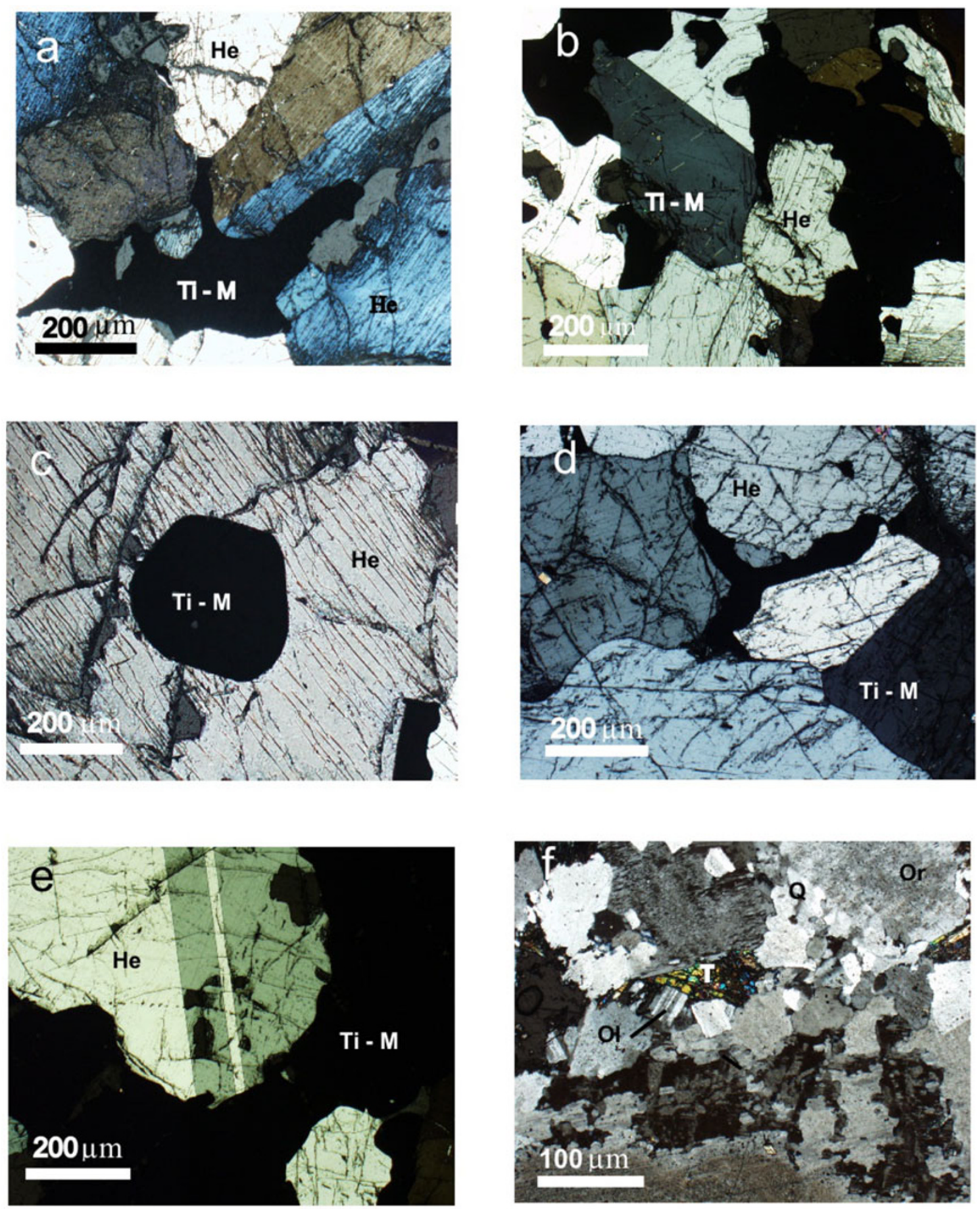

Fig. 3. Representative photomicrographs of the ultramafic, breccia, and granodiorite (ijolite) rocks using crossed nichols and transmitted light. (a) Ultramafic, coarse grain of $\mathrm{He}$ forming granular texture. Ti-M occupy open spaces between He grains. (b) Ultramafic, Ti-M ocuppying open spaces among He grains. (c) Ultramafic, He with a subrrounded inclusion of Ti-M? (d) Ultramafic, granular mosaic of He with Ti-M. (e) Breccia, Ti-M surrounding a He grain in the breccia rock. (f) Granodiorite, granular mosaic of $\mathrm{Or}, \mathrm{Ol}, \mathrm{Q}$, and $\mathrm{T}$ in the ijolite. $\mathrm{He}=$ hedenbergite, Ti-M $=$ titanomagnetite, $\mathrm{Q}=$ quartz, $\mathrm{Or}=$ orthoclase, $\mathrm{Ol}=$ oligoclase, $\mathrm{T}=$ tremolite.

netite fills fractures mainly in calcite. The ultramafic rock is formed by hedenbergite with the open spaces occupied by titanomagnetite and associated ilmenite lamellae-trellis type (Fig. 3(e)).

\subsection{Ijolite}

The intrusive rock, ijolite from site MM- 8 , is formed by a granular mosaic of coarse grains $(320-500 \mu \mathrm{m})$, Na plagioclase (andesine and oligoclase), orthoclase, and quartz (Fig. 3(f)). Embedded in plagioclase are apatite, zircon and sphene euhedral crystals of $<5 \mu \mathrm{m}$. Magnetic minerals are: titanomagnetite, titanomaghemite, and ilmenite. Titanomagnetite is composed of subhedral to euhedral crystals up to $25 \mu \mathrm{m}$ in size with ilmenite lamellae-sandwich type. These intergrowths typically develop at temperatures higher than $600^{\circ} \mathrm{C}$ (Haggerty, 1976) and, consequently, the NRM carried by these samples is TRM magnetization.

The main opaque-ore in Cajati Mine is magnetite and titanomagnetite hosted in carbonatites, ultramafic rocks, and breccias (Fig. 4). Carbonatites generally contain welldeveloped magnetite crystals associated with the calcite and 

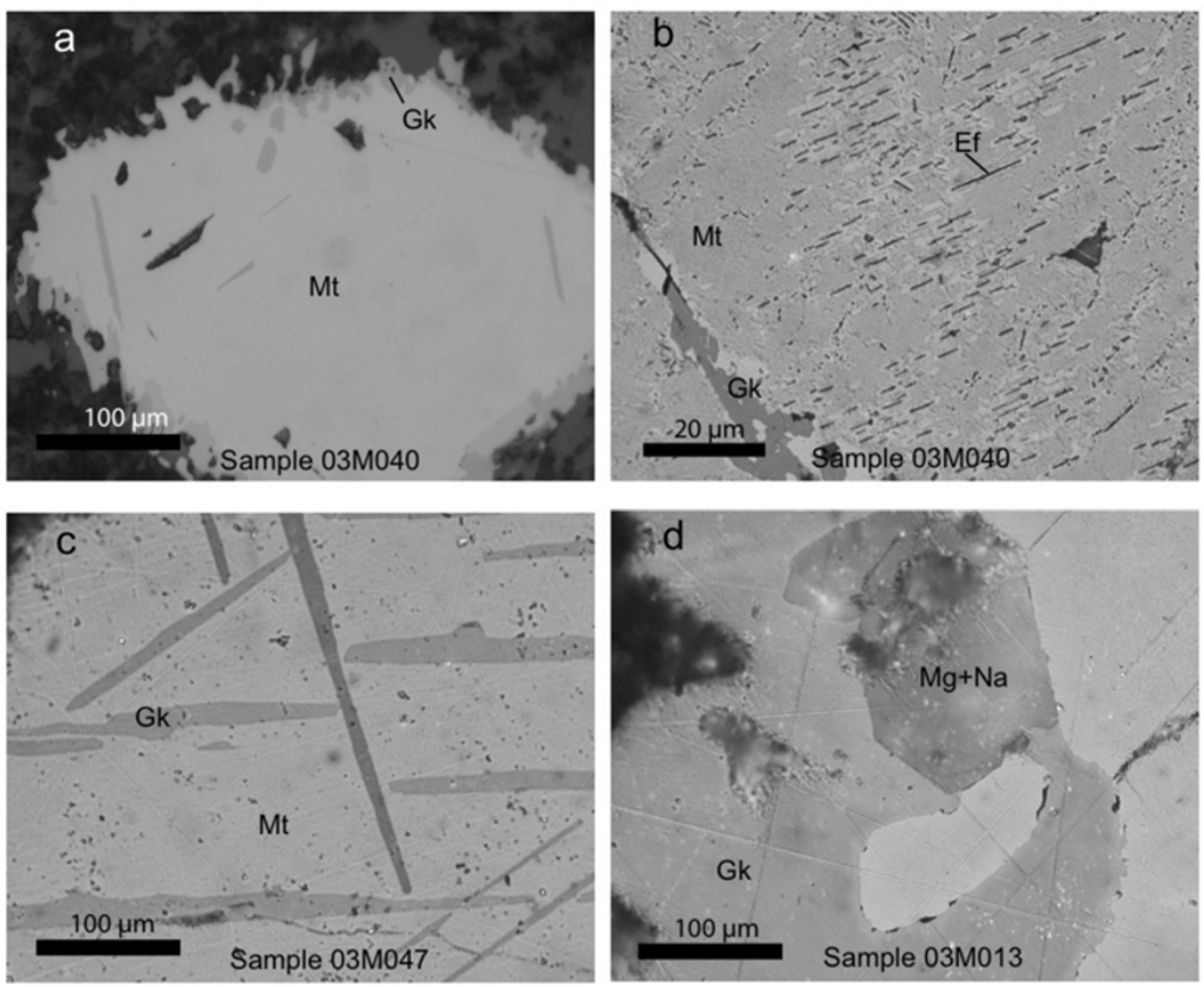

Fig. 4. Representative photomicrographs of the ultramafic, breccia and carbonatitic rocks using reflected light. (a) Sample 03M040, ultramafic rock. Magnetite with skeletal borders produced by geikielite. (b) Sample 03M040, ultramafic rock. Titanomagnetite associated to ferrian spinel (black) partly replaced by geikielite along fractures. (c) Sample 03M047, breccia. Magnetite with geikielite lamellae following the crystallographic planes. (d) Sample 03M013, carbonatite. Magnetite with $\mathrm{Mg}$ and $\mathrm{Na}$ silicate inclusions partly surrounded by geikielite. $\mathrm{M}=\mathrm{magnetite}, \mathrm{Mg}=$ magnesium, $\mathrm{Na}=$ sodium, $\mathrm{G}=$ geikielite.

dolomite. Ultramafic rocks have a complex mineralogy, with titanomagnetite being the main oxide, generally with graphic intergrowths of the ilmenite lamellae-trellis type and ferrian spinel. Acicular geikielite was also identified as growing wollastonite through fractures. The brechoid rock is characterized by ore-magnetite with geikielite lamellae and surrounding geikielite. Magnetite primarily fills fractures in hyperstene and calcite.

\section{Magnetic Measurements}

Rock-magnetic research was carried out to identify the magnetic carriers responsible for the magnetization and to obtain information about their magnetic stability.

5.1 Natural remanent magnetization intensity, bulk suceptibility, and Koenigsberger ratio $(Q)$

NRM intensity $\left(M_{\mathrm{o}}\right)$, susceptibility $(k)$ at room temperature, and the Koenigsberger ratio $Q=M_{\mathrm{o}} / k H$ (calculated for the present geomagnetic field) are shown in Table 1 . Koenigsberger ratios attest the relative significance of remanent and induced magnetization, with remanence dominant for $Q>1$. Differences in $M_{\mathrm{o}}$ and $k$ are due mainly to two factors: different initial volume content of magnetite, and the development of weakly magnetic or nonmagnetic phases created during the oxidation or alteration of the rocks.

\subsection{Alternating field and thermal demagnetizations}

Both AF and stepwise thermal demagnetization were completed. The low-field susceptibility at room temperature was measured after each step of thermal demagnetiza- tion. We determined the directions of characteristic magnetization using principal component analysis (Kirschvink, 1980). However, the cautiously sampling procedure, directions for each site, show that medium-to-high withinsite angular dispersions and the site-mean directions are scattered. This is due to potential chemical remagnetization, mainly for the phoscorite samples. A further possible source of discordant directions may originate from the small physical movement of the ores during faulting or mining.

Vector plots show a different behavior for each rock type. In general, two magnetization components are found (Fig. 5(a)), with the softer low temperature $\left(<200^{\circ} \mathrm{C}\right)$ or low stability $(<10 \mathrm{mT})$ component being well defined. The characteristic remanence is defined above $500^{\circ} \mathrm{C}$ or $>30 \mathrm{mT}$ for the ore and the hosted samples (MM1-MM3 and MM4-MM7, phoscorite and pyroxenite, respectively) and may also correspond to a chemical overprint.

For the pyroxenite samples (MM4-MM6 sites), the general behavior of all samples yields reasonably linear and stable magnetic components (Fig. 5(b)). The stability is further borne out by the intensity-decay curves, which show that most probably only two components of magnetizations are present. A major part of magnetization is removed above $450^{\circ} \mathrm{C}$ or $20 \mathrm{mT}$, which probably points to the presence of magmatic or hydrothermal (titano)magnetite as well as (titano)hematite, as observed under reflected light microscopy. Some of these rock types are reasonably magnetic, producing substantial magnetic anomalies, i.e., pyroxenite samples (MM4-MM6 sites), $Q$ of 6-10, and rema- 
Table 1. Rock magnetic parameters of host and minerals from Cajati ore deposit.

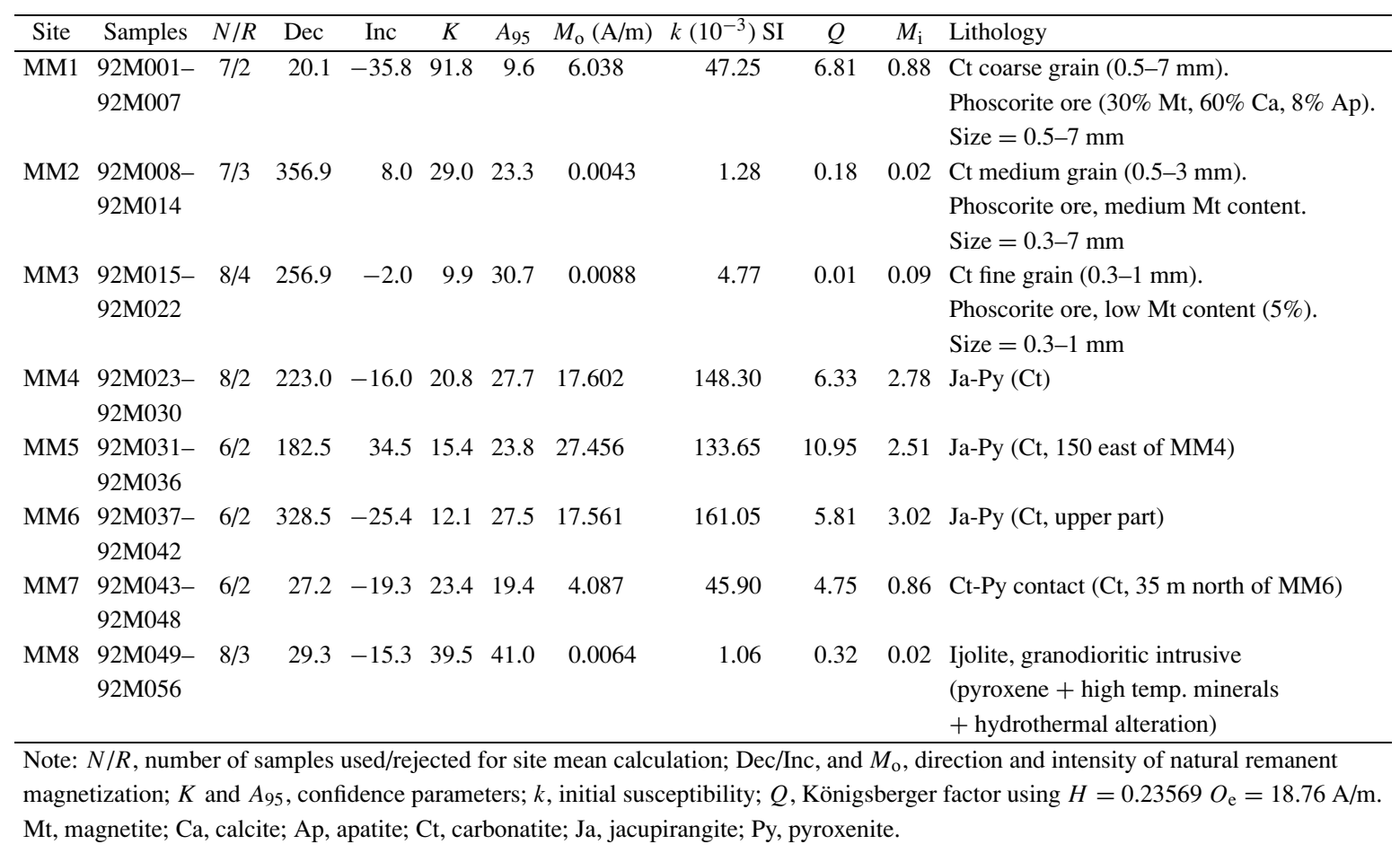

nence of $17-27 \mathrm{~A} / \mathrm{m}$. For the highly magnetic rock types, the scatter of directions may also reflect inhomogeneous internal (self-demagnetizing) fields.

\subsection{Continuous susceptibility measurements}

Magnetic susceptibility was measured as a function of temperature. One sample from each site was heated up to $600^{\circ} \mathrm{C}$ at a heating rate $20^{\circ} \mathrm{C} / \mathrm{min}$ and then cooled at the same rate. Curie temperatures were determined by the Prévot et al. (1983)'s method. Samples from MM4 to MM6 sites, with high magnetic susceptibility, show that the more magnetic phase appears to be magnetite, as indicated by the single Curie temperature of $578^{\circ} \mathrm{C}$ on the heating branch below $600^{\circ} \mathrm{C}$. Maghemite was probably formed during their cooling process (Fig. 6(c), (d), (e)). Some of these samples show also a slight contribution of hematite components. Curves of Fig. 6(a), (b), (f) indicate that magnetite and hematite are almost pure phases, or close to end-member, showing a reasonable reversible behavior (sites: MM1MM3 and MM8).

Alternatively, low-temperature (from liquid nitrogen $\left.\left(-196^{\circ} \mathrm{C}\right)\right)$ to room temperature susceptibility was recorded using the same apparatus. Three typical curve shapes were observed during low- $T$ susceptibility experiments (Fig. 7). The curve from the sample from the MM1 to MM3 sites shows a monotonic decrease from near $-175^{\circ} \mathrm{C}$, which probably indicates Verwey transition, characteristic of almost pure multidomain (MD) magnetite (Fig. 7(a)). Dunlop and Özdemir (1997) show that this transition may be largely suppressed for the titanomagnetites with variable titanium content. Alternatively, samples from sites MM4 to MM6 show a similar behavior, with a displacement of the inflection point about $15^{\circ} \mathrm{C}\left(-160^{\circ} \mathrm{C}\right)$ (Fig. 7(b)). They may also correspond to non-stoichiometric (partially oxidized) magnetite. In a unique case, a quite well-defined minimum was detected (site MM8) at approximated $-155^{\circ} \mathrm{C}$ and a maximum at about $-140^{\circ} \mathrm{C}$ (Fig. 7(c)). This temperature is the Vervey transition indicative of the presence of MD magnetite, or equidimensional single-domain (SD) magnetite grains that have negligible shape anisotropy.

\subsection{Hysteresis properties}

Several small chips of rocks from the paleomagnetic specimens were used for hysteresis measurements at room temperature from all studied units in fields up to $1.2 \mathrm{~T}$. The saturation remanent magnetization $\left(J_{\mathrm{rs}}\right)$, the saturation magnetization $\left(J_{\mathrm{s}}\right)$, and coercive force $\left(H_{\mathrm{c}}\right)$ were calculated after correction for the paramagnetic contribution. The coercivity of remanence $\left(H_{\mathrm{cr}}\right)$ was determined by applying progressively increasing backfield after saturation. Some typical hysteresis plots are shown in Fig. 8. The $H_{\mathrm{cr}} / H_{\mathrm{c}}$ ratio ranges from 0.25 to 0.83 and $M_{\mathrm{rs}} / M_{\mathrm{s}}$ varies between 0.024 and 0.191 (Table 2). The hysteresis parameter plot indicates that almost all values fall in a novel region of the Day plot, like the values reported for oceanic dolerites, gabbros, and serpentinized peridotites, parallel to but below the magnetite SD + MD mixing curves (Fig. 9(a), Day et al., 1977; Dunlop, 2002a, b). Dunlop (2002b), states that the interpretation of this new region is not clear. Tracking according to Tauxe and Bertram (2002), we plot hysteresis parameters, illustrating that most fit in the vortex remanent state contribution to PSD hysteresis behavior as suggested by Williams and Dunlop (1995) (Fig. 9(b)). Hysteresisshaped loops and coercivities measured in these samples suggest magnetite as the main magnetic mineral, which is supported by microscopic observations.

Samples with relatively high susceptibilities ( $>0.05 \mathrm{SI}$, site MM1) contain abundant magnetite $(30 \%)$. The $M_{\mathrm{S}}$ for these samples are much higher than that for the lowsusceptibility intrusive hydrothermally altered sample (site 
a) Sample 92M032 (Site MM5)
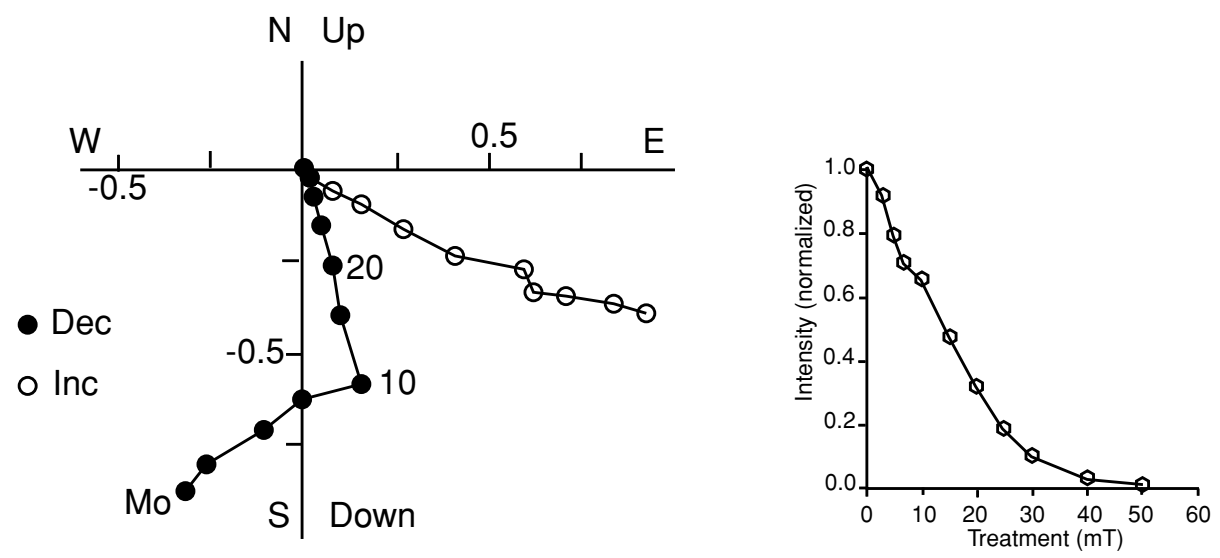

b) Sample 92M040 (Site MM6)
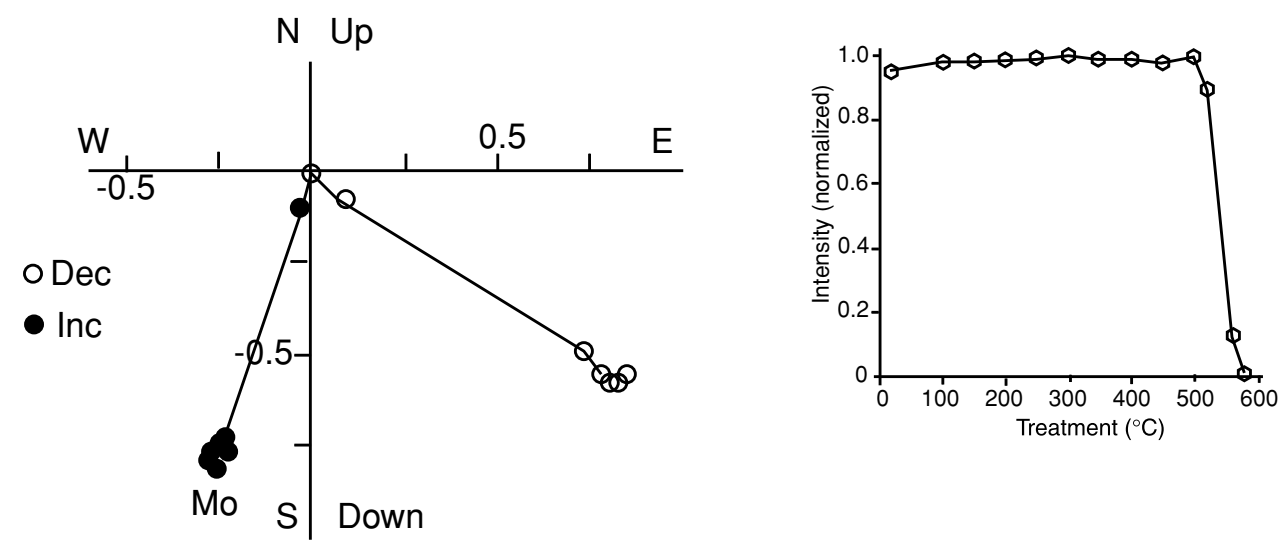

Fig. 5. Orthogonal vector plots of remanent magnetization for representative samples. The numbers refer to the temperatures (magnetic field) in ${ }^{\circ} \mathrm{C}$ $(\mathrm{mT})$. Filled circles, projections onto the horizontal plane, open circles, projections onto the vertical plane.

Table 2. Hysteresis parameters.

\begin{tabular}{cccccccc}
\hline Site no. & Sample & $M_{\mathrm{r}}\left(\mu \mathrm{A} \mathrm{m}^{2}\right)$ & $M_{\mathrm{s}}\left(\mu \mathrm{A} \mathrm{m}^{2}\right)$ & $M_{\mathrm{r}} / M_{\mathrm{s}}$ & $H_{\mathrm{c}}(\mathrm{mT})$ & $H_{\mathrm{cr}}(\mathrm{mT})$ & $H_{\mathrm{cr}} / H_{\mathrm{c}}$ \\
\hline MM1 & $03 \mathrm{M} 001$ & 29.1 & 1190 & 0.024 & 1.65 & 0.292 & 0.18 \\
MM2 & $03 \mathrm{M} 014$ & $10.2^{*}$ & $173^{*}$ & 0.059 & 5.64 & 1.40 & 0.25 \\
MM3 & $03 \mathrm{M} 022$ & $60.1^{*}$ & $407^{*}$ & 0.148 & 11.7 & 6.27 & 0.54 \\
MM4 & $03 \mathrm{M} 027$ & 14.5 & 95.3 & 0.152 & 11.3 & 7.97 & 0.71 \\
MM5 & $03 \mathrm{M} 033$ & 60.5 & 316 & 0.191 & 14.3 & 11.8 & 0.83 \\
MM6 & $03 \mathrm{M} 040$ & 137 & 764 & 0.179 & 11.6 & 8.37 & 0.72 \\
MM7 & $03 \mathrm{M} 045$ & 11.4 & 102 & 0.112 & 11.9 & 8.70 & 0.73 \\
MM8 & $03 \mathrm{M} 051$ & $112^{*}$ & 1.55 & 0.072 & 9.99 & 4.73 & 0.47 \\
\hline Note: $M_{\mathrm{r}}$, remanent magnetization; $M_{\mathrm{s}}$, saturation magnetization; $H_{\mathrm{c}}$, coercive force; $H_{\mathrm{cr}}$, coercivity of remanence. $(*)$ values are \\
in nA m ${ }^{2}$.
\end{tabular}

MM8). $M_{\mathrm{r}} / M_{\mathrm{s}}$ ratios are low, from 0.02 to 0.2 . Coercivity values range from 2 to 14 and the coercivity of remanence from 0.3 to 12 . $H_{\mathrm{cr}} / H_{\mathrm{c}}$ ratios are low, from 0.2 to 0.8 . At room temperature, hysteresis loops are symmetrical about the origin. All samples are dominated by magnetite, and some of these show the superparamagnetic contribution.

\section{Discussion and Conclusions}

The analyses of the Cajati deposit provide evidence that the iron ore is neither purely hydrothermal nor volcanic in origin. The ores were formed from magnetite-rich magmas, hydrothermally altered and intruded at a crustal depth in excess of $600 \mathrm{~m}$. Thus, a rather complex sequence of events has occurred to produce this deposit.

The mineralogical and textural association between magnetite and magnesioferrite in the carbonatite and the titano- 

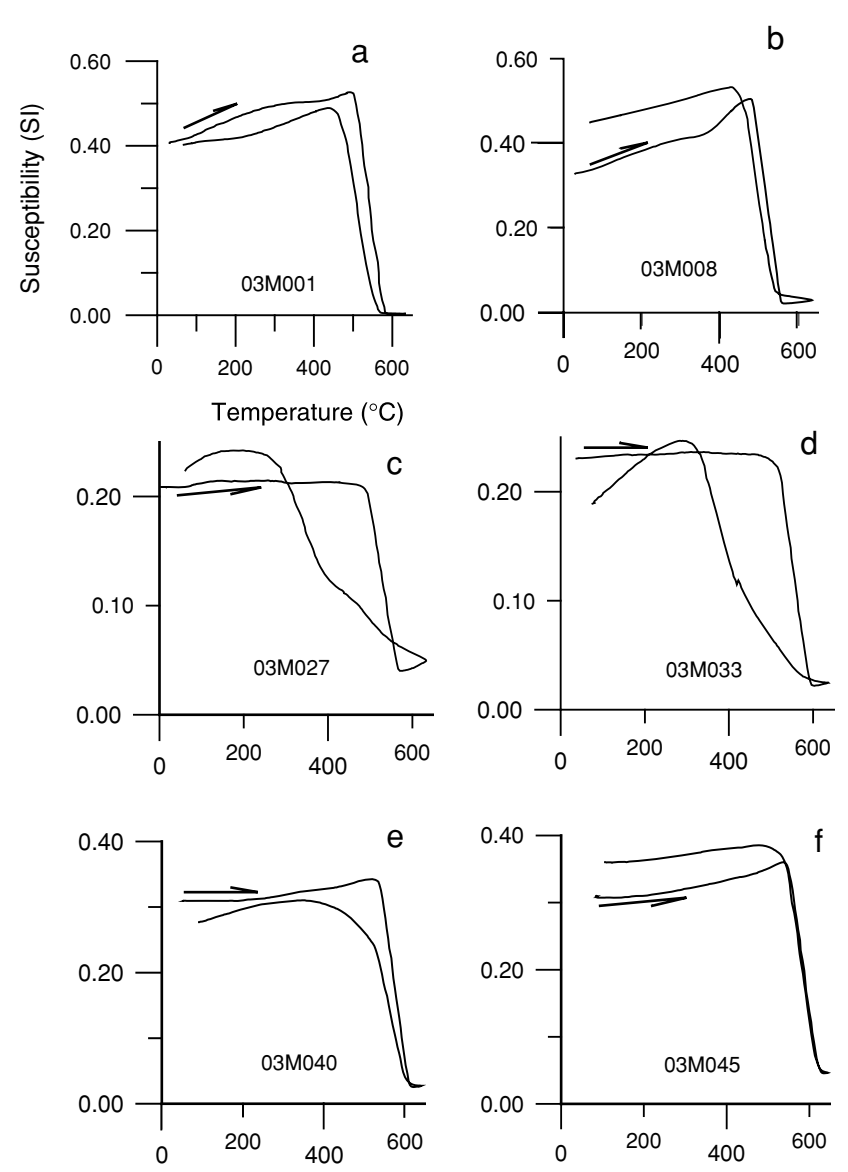

Fig. 6. High-temperature $k-T$ curves. Arrows indicate the heating curve.

magnetite and magnesioferrite-Ti mineralization in the pyroxenite of hedenbergite seem to be analog mineralizations strongly related to the ionic substitution of $\mathrm{Fe}^{2+}$ by $\mathrm{Mg}$. This substitution was probably due to the circulation of hydrothermal solutions through fissures, open spaces, and porous zones in both rock types. At high pressures, hydrothermal solutions are forced to react with the host rock, mainly along fractured areas, by heat and chemical components transmitted to the system, resulting in mineralization coming from the magmatic to hydrothermal. The paragenetic sequence of both types of mineralization is noticeable by its order of crystallization differentiation, where the hydrothermal phase is formed the latest. Hydrothermal processes under these conditions occur in the pressure range under $700^{\circ} \mathrm{C}$, that is, the fluid formation environment (Tornos, 1997).

The progressive change in the primary mineralization is produced by a complex system of hydratation reactions and ionic exchange between the primary mineralization of the intrusive massif and solutions, changing the composition of the hydrothermal fluid, its $\mathrm{pH}$, and its redox state (Tornos, 1997). The mineralization evolves and its chemistry and textural relations (size-shape) are drastically affected through time up to the equilibrium. This process of progressive equilibrium could explain the formation of magnesioferrite, ilmenite, and Fe-spinel nanoparticles (Alva-Valdivia et al., in preparation).

Evidence of hydrothermal processes in both types of rock
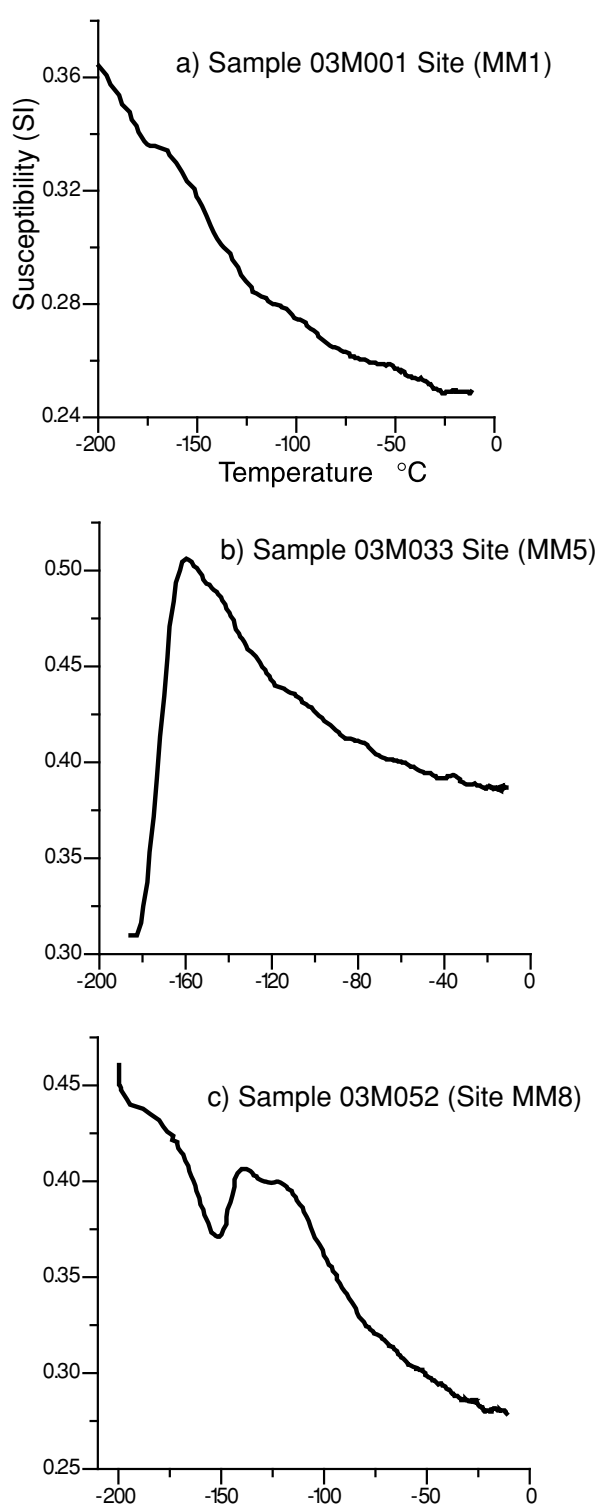

Fig. 7. Low-temperature $k-T$ curves.

is indicated by the following factors:

a) Texture (size-shape). In the carbonatite, the magnetite is massive and forms around the minerals of the rock as apatite, forsterite, carbonates, and phlogopite. This suggests that their post-crystallization to these minerals during the latest phase of magmatic differentiation could be a hydrothermal high temperature phase. In the pyroxenite, the titanomagnetite forms a metasomatic texture with the pyroxene (hedenbergite) grains, providing evidence for a reaction of a hydrothermal fluid with primary mineralization (titanomagnetite with ilmenite exsolutions) of the intrusive rock previously consolidated. This event favored the formation of magnesioferrite-Ti nanoparticles.

b) Ionic exchange, $\mathrm{Fe}^{2+}$ by $\mathrm{Mg}$, occurs in the metallic mineralization of both rock types. In the carbonatites, the magnetite contains variable amounts of $\mathrm{Mg}$ and up to $4 \% \mathrm{MgO}$. When the $\mathrm{MgO}$ content increases up to $10 \%$, the magnetite is transformed to magnesioferrite. 

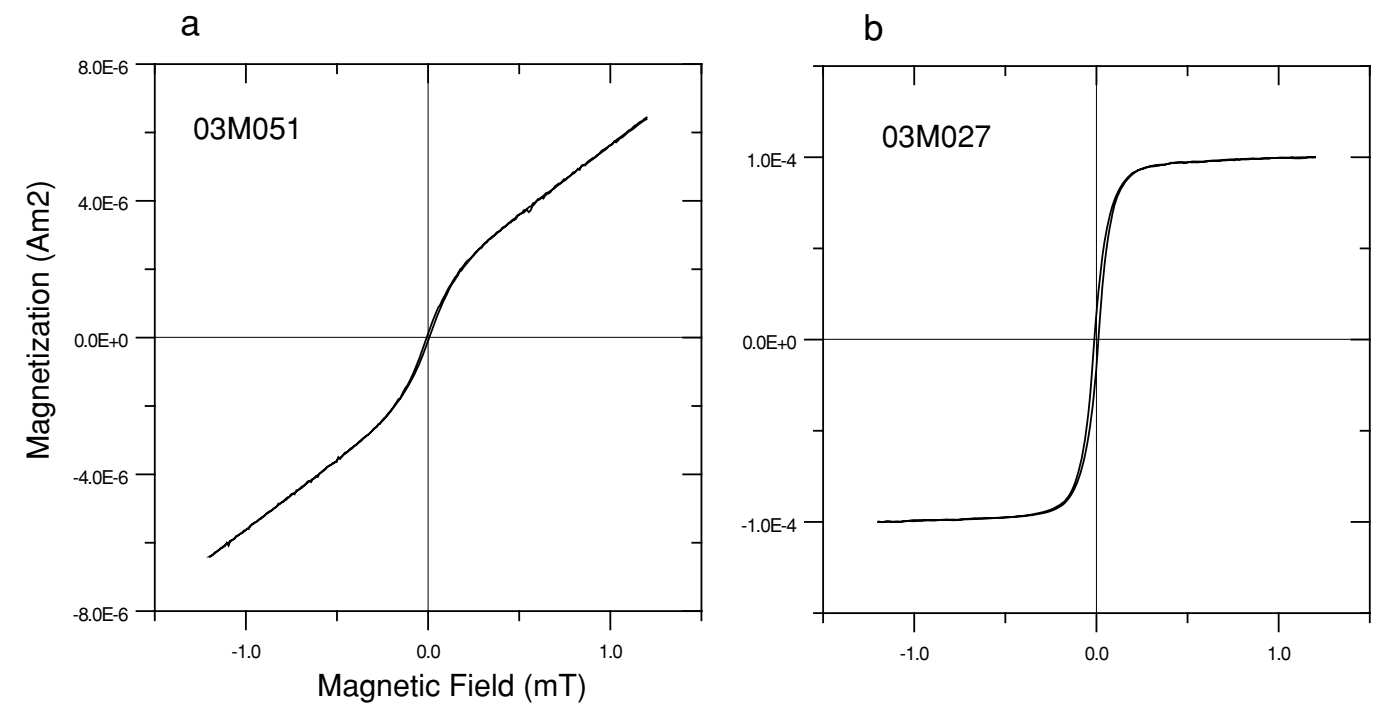

Fig. 8. Hysteresis loops without paramagnetic correction for typical samples. Rock samples and corresponding sites are: (a) Ijolite, MM8 and (b) Jacupirangite-pyroxenite, MM4.
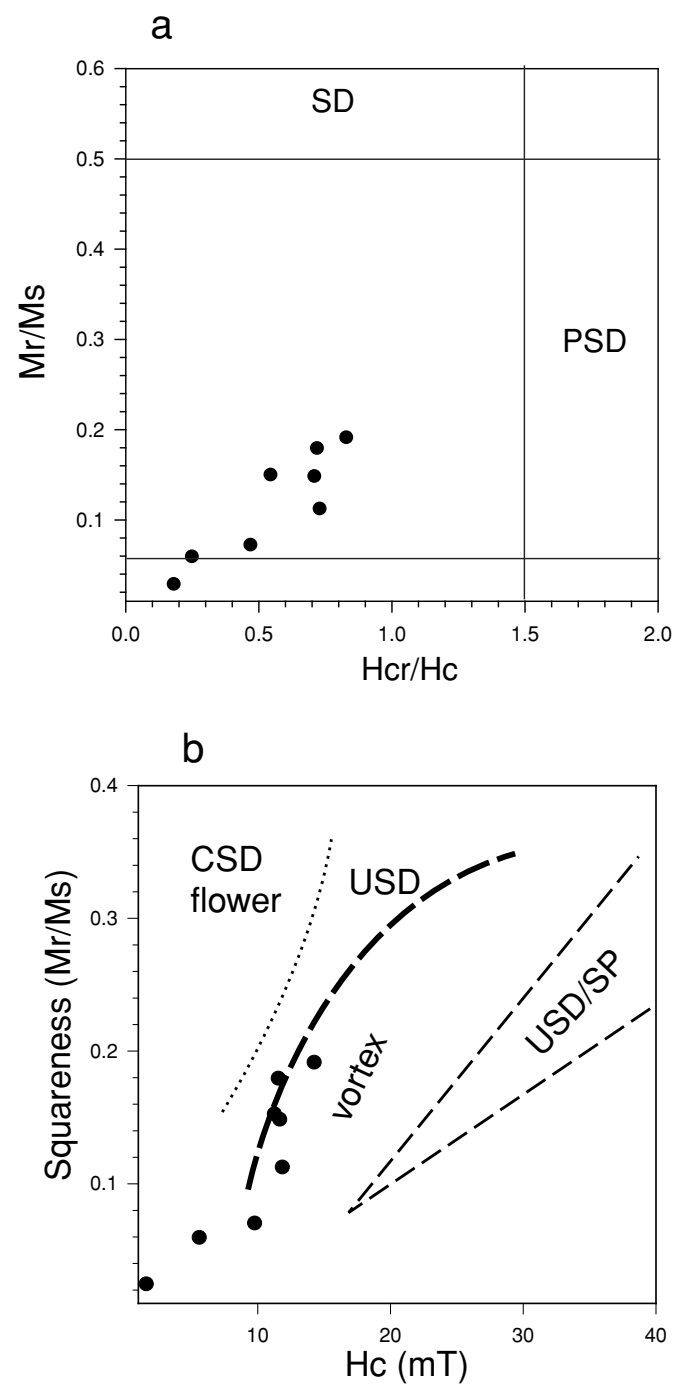

Fig. 9. Typical hysteresis plots parameters. (a) Fields for SD, PSD, and MD grains (Dunlop and Özdemir, 1997), shown for visual guides are pertinent to magnetite and can not be certainly effective to other minerals; (b) vortex remanent state.
The magnetite generally shows reaction borders when it is in contact with dolomite. In the carbonatite, Ti was not detected in the selected micro-zones of magnetites and magnesioferrites, contrary to the pyroxenite samples that show up to $10 \%$ of Ti into the titanomagnetite and magnesioferrite.

The textural relationship of magnetite, aragonite, and pyrite and its mineralogical association with the primary minerals, suggest a deposition soon after carbonatite formation as a resulting of hydrothermalism.

Relatively high $Q$ ratios $(\geq 5)$ for Jacupirangitepyroxenite (Table 1) may indicate a TRM origin for the magnetization. The principal carriers are Ti-poor titanomagnetites, with some deuteric oxy-exsolution products. These rocks have the highest NRM intensity and susceptibility values, resulting in high $Q$ ratios, suggesting a wide range of magnetite grain sizes carrying the NRM.

The vector plots for the pyroxenite samples, in general, show reasonably linear and stable magnetic components (Fig. 5(b)). The intensity decay curves show that most likely only two components of magnetizations are present. A principal part of magnetization is removed above $450^{\circ} \mathrm{C}$ or $20 \mathrm{mT}$, which suggests the presence of magmatic or hydrothermal (titano)magnetites and (titano)hematites, as observed. The scatter of directions for the strongly magnetic rock types may also reflect inhomogeneous internal (selfdemagnetizing) fields.

Generally speaking, possible significant differences are found in the directions of remanence carried, in particular by the magnetic minerals of sites 3 to 5 , which suggests that the hydrothermal event occurred some considerable time after the extrusion and cooling.

Continuous susceptibility measurements with increasing temperature show that the main magnetic phase seems to be magnetite. Maghemite is probably produced during the cooling process (Fig. 6). These curves indicate that magnetite and hematite are almost pure phases showing a reasonable reversible behavior. 
Susceptibility recorded at the low-temperature $\left(-196^{\circ} \mathrm{C}\right)$ to room temperature transition produces three typical curves (Fig. 7). All of these suggest magnetite and distinct magnetic domain state (from MD to SD).

Hysteresis parameters indicate that nearly all values for these ratios (Table 2) are too small to be set in any grain size region (Fig. 9(a)), instead, they fall in a different region of the Day plot, parallel to but below magnetite SD + MD mixing curves, like those obtained for dolerites and serpentinized gabbros and peridotites of layer 2, 3, and 4 from the deeper oceanic crust (Dunlop, 2002b). The interpretation of this new region is unclear. However, the loops seem to be typical of magnetite affected by some superparamagnetic contribution behavior. Figure 9(b) suggests that magnetization resides in the vortex remanent state contribute to PSD hysteresis behavior (Williams and Dunlop, 1995).

Acknowledgments. We are grateful for the kind cooperation of the engineering staff of Planejamento de Lavra/Geologia, BUNGE Fertilizantes S/A Unidade Cajati. This research was funded by the CONACyT project No. 32756-T and DGAPA-UNAM research project IN110308 and 102007 . We acknowledge the critical revision of this manuscript by Dr. I. Blanco and Dr. P. Schmidt, which greatly improved this work.

\section{References}

Alva-Valdivia, L. and J. Urrutia-Fucugauchi, Rock magnetic surveys in the iron ore deposit of El Encino, Mexico, J. South Am. Earth Sci., 8, 209220, 1995.

Alva-Valdivia, L. and J. Urrutia-Fucugauchi, Rock magnetic properties and ore microscopy of the iron ore deposit of Las Truchas, Michoacan, Mexico, J. Appl. Geophys., 38, 277-299, 1998.

Alva-Valdivia, L., J. Urrutia-Fucugauchi, H. Böhnel, and D. MoranZenteno, Aeromagnetic anomalies and paleomagnetism in Jalisco and Michoacan, southern Mexico continental margin, and their implications for iron-ore deposits exploration, Tectonophysics, 192, 169-190, 1991.

Alva-Valdivia, L. M., J. Urrutia-Fucugauchi, A. Goguichaichvili, and D. Dunlop, Magnetic mineralogy and properties of the Peña Colorada iron ore deposit, Guerrero Terrane: implications for magnetometric modeling, J. South Am. Earth Sci., 13, 415-428, 2000.

Alva-Valdivia, L. M., J. Urrutia-Fucugauchi, A. Goguitchaichvili, and W. Vivallo, Rock-magnetism and ore microscopy of magnetite-apatite ore deposit from Cerro de Mercado, Mexico, Earth Planets Space, 53, 181$192,2001$.

Alva-Valdivia, L. M., M. L. Rivas-Sánchez, A. Gonzalez, A. Goguitchaichvili, J. Urrutia-Fucugauchi, J. Morales, and W. Vivallo, Integratted magnetic studies of the El Romeral Iron-ore Deposit, Chile: implications for the ore genesis and modeling magnetic anomalies, J. Appl. Geophys., 53, 137-151, 2003a.

Alva-Valdivia, L. M., M. L. Rivas, A. Goguitchaichvili, J. UrrutiaFucugauchi, J. A. Gonzalez, J. Morales, S. Gómez, F. Henríquez, J. O. Nyström, and R. H. Naslund, Rock Magnetic and Oxide Microscopy Studies of the El Laco, Iron-Ore Deposits, Chilean High Andes and Implications for Magnetic Anomaly Modeling, Int. Geol. Rev., 45, 533547, 2003b.

Alves, P. R. and R. D. Hagni, Bunge's Cajati apatite mine, SE Brazil: mineralogy and petrography of the carbonatite intrusions and the relationship to mineral processing, in Appl. Mineral., edited by Pecchio et al., 653-656, ICAM-BR, Sao Paulo, ISBN 85-98656-02-X, 2004.

Bonás, T. B., Consolidação de critérios de descrição litológica para o minério apatítico do complexo alcalino de Jacupiranga, 48 pp., Mono- grafia de trabalho de formatura, IG-USP, 2001.

Brandão, A. G. and L. M. Sant'Agostino, Technological characterization of carbonatitic raw material manufacture from Cajati (SP), in Appl. Mineral., edited by Pecchio et al., 977-980, ICAM-BR, São Paulo, ISBN 85-98656-02-X, 2004.

Day, R., M. Fuller, and V. A. Schmidt, Hysteresis properties of titanomagnetites: grain size and compositional dependence, Phys. Earth Planet. Inter., 13, 260-267, 1977.

Direen, N. G., K. M. Pfeiffer, P. W. Schmidt, and M. Sexton, Strong remanent magnetization in Pyrrothite: a structurally-controlled example from the Paleoproterozoic Tnami Orogenic gold province, northern Australia, Precam. Res., 165, 96-106, 2008.

Dunlop, D. J., Theory and application of the Day plot $\left(M_{\mathrm{rs}} / M_{\mathrm{s}}\right.$ versus $\left.H_{\mathrm{cr}} / H_{\mathrm{c}}\right) 2$. Application to data for rocks, sediments, and soils, J. Geophys. Res., 107(B3), doi:10.1029/2001JB000487, 2002a.

Dunlop, D. J., Theory and application of the Day plot $\left(M_{\mathrm{rs}} / M_{\mathrm{S}}\right.$ versus $\left.H_{\mathrm{cr}} / H_{\mathrm{c}}\right) 1$. Theoretical curves and tests using titanomagnetite data, $J$. Geophys. Res., 107(B3), doi:10.1029/2001JB000486, 2002 b.

Dunlop, D. and O. Özdemir, Rock-Magnetism, fundamentals and frontiers, 573 pp., Cambrige University Press, 1997.

Haggerty, S. E., Oxidation of opaque mineral oxides in basalts, in Oxide Minerals (Short Course Notes), Miner. Soc. Am., edited by D. Rumble, 3, 1-100, 1976.

Henkel, H., Standard diagrams of magnetic properties and density-a tool for understanding magnetic petrology, J. Appl. Geophys., 32, 43-53, 1994.

Kirschvink, J. L., The least-square line and plane and analysis of palaeomagnetic data, Geophys. J. R. Astron. Soc., 62, 699-718, 1980.

Melcher, G. C., Nota sobre os distrito Alcalino de Jacpiranga, São Paulo Div. Geol. Min., 84, 1954.

Prévot, M., E. A. Mainkinen, S. Grommé, and A. Lecaille, High paleointensity of the geomagnetic field from thermomagnetic studies on rift valley pillow basalts from the middle Atlantic ridge, J. Geophys. Res., 88, 2316-2326, 1983.

Ruberti, E., C. B. Gomes, and G. C. Melchor, The Jacupiranga Carbonatite Complex: geological and petrological aspects of the Jacupiranga alkaline-carbonatite association, southern Brazil, Post-Congress Field Trip Aft 08 Guidebook, International Geological Congress, Part I: 1-21, Rio de Janeiro, Brazil, 2000

Schmidt, P. W., S. A. McEnroe, D. A. Clark, and P. Robinson, Magneic properties and potential field modeling of the Peculiar Knob metamorphosed iron formation, South Australia: An analog for the source of the intense Martian magnetic anomalies?, J. Geophys. Res., 112, B03102, doi:10.1029/2006JB004495, 2007.

Skilbrei, J. R., T. Skyseth, and O. Olesen, Petrophysical data and opaque mineralogy of high-grade and retrogressed lithologies: implications for the interpretation of aeromagnetic anomalies in Northern Vestranden, Central Norway, Tectonophysics, 192, 21-31, 1991.

Tauxe, L. and H. N. Bertram, Physical interpretation of hysteresis loops: micromagnetic modelling of fine particle magnetite, Geochem. Geophys. Geosyst., doi:10.1029/2001GC000280, 2002.

Tornos, D., Procesos de alteración y relleno hidrotermal sobre rocas silicoaluminícas, Atlas de asociaciones minerales en lamina delgada, Universidad de Barcelona, 249-271, 1997.

Vahle, C., A. Kontny, H. P. Gunnlaugsson, and L. Kristjansson, The Stardalur magnetic anomaly revisited-New insights into a complex cooling and alteration history, Phys. Earth Planet. Inter., 164, 119-141, 2007.

Williams, W. and D. J. Dunlop, Simulation of magnetic Hysteresis in pseudo-single domain grains of magnetite, J. Geophys. Res., 100, 38593871,1995 .

L. M. Alva-Valdivia (e-mail: lalva@geofisica.unam.mx), M. Perrin, M. L. Rivas-Sánchez, A. Goguitchaichvili, H. López-Loera, O. F. Lopes, and T. B. Bonás 